\title{
Chapter 8 \\ Conclusion: Fundamental Merits, Embedded Deficiencies, and Urgent \\ Problems of the U.S. Presidential \\ Election System
}

The Conclusion briefly summarizes fundamental merits, substantial deficiencies, and certain problems of the currently existing U.S. presidential election system, which have been discussed in the book. Also, it outlines seven major topics relating to presidential elections on which public debates are likely to focus in the years to come: (a) what rules for electing a President and a Vice President are the fairest, (b) how to suppress voter fraud while not suppressing voter turnout; (c) how to improve the Election Day procedures that affect the integrity of the election process; (d) how to broadcast polling results as election campaign develops to avoid "brainwashing" the voters and not to reduce the turnout, (e) what voting technologies can assure the American people that every vote cast is counted, (f) how to improve civics education relating to the election system to make every eligible voter interested in voting in presidential elections, and $(\mathrm{g})$ who should govern the national televised presidential debates, and how these debates should be governed.

The U.S. presidential election system was proposed by the Constitutional Convention participants in Philadelphia in 1787. Its basic principles were set in Article 2 of the Constitution, but the proposed system was modified as a result of the Twelfth Amendment ratification in 1804. Since then, Amendments 20, 22, 23 , and 25 , which directly affect the structure and work of the presidential election system, and Amendments 13, 14, 15, 19, 24, and 26, which deal with the rights of American citizens to participate in all U.S. elections, including presidential ones, have been ratified. However, the basic principles of the system, set in Article 2 and Amendment 12, have practically remained unchanged.

The essence of these principles can be described as follows: Only the states and the District of Columbia (since 1964) rather than the American people can elect a U.S. President and a U.S. Vice President, and only the states have two attempts to elect these two executives. The first attempt is implemented by the states (and, since the 1964 presidential election, by the District of Columbia) via the Electoral 
College, which chooses both a President and a Vice President. Should this first attempt fail (and this happened twice, in the 1800 and in the 1824 elections), the second attempt to choose both executives is given to the states only. This second attempt is implemented via Congress, where the House of Representatives chooses a President, and the Senate chooses a Vice President.

Many constitutional scholars and specialists on the American history strongly believe that the Constitutional Convention participants (the Founding Fathers) attempted to create a republic of independent, equal states, rather than a democracy (as a form of governing the country). They believe that the Founding Fathers wanted to avoid the "tyranny of majority" and to provide the independence and balance of all the three branches of authorities in the country-executive, legislative, and judicial - particularly, by rejecting the idea of direct presidential elections by the American people. Some of these scholars and specialists believe that the Founding Fathers were sure that a mandate from the nation to the Chief Executive, on who the Constitution vests all the executive power in the country, would give this branch of the country's authorities a more weight in governing the country than each of the other two branches would have.

\subsection{Fundamental Merits of the System}

A brief summary of the fundamental merits of the existing U.S. presidential election system to follow should be viewed as the author's attempt to analyze to what extent the existing system corresponds to underlying basic ideas and principles reflected in the Constitution and in the Supreme Court decisions relating to U.S. presidential elections. All the reasoning presented in the text does not reflect any emotional perceptions of this election system that American voters and residents may have.

1. In the absence of national and international disasters, the work of the U.S. presidential election system always ends on Inauguration Day. Either an elected President or a person from a set of eligible persons is assigned President and is sworn in by taking the oath. This set includes the list of eligible persons determined by a document adopted by Congress in line with the requirements of the Twentieth Amendment. Currently, the Presidential Succession Act of 1947 is this document (though its constitutionality is questioned by some prominent constitutional scholars). This act (a) has done away with the Presidential Succession Act of 1886, and (b) has reinstated the order of the first two people on the list that existed in the initial Presidential Succession Act of 1792.

The state legislature from each of the fifty states and that from the District of Columbia appoint state and D.C. presidential electors, respectively. The appointed electors are to vote for President and for Vice President on the same day in the places of their residence (states and D.C.). Both state and D.C. 
legislatures are free to choose a manner of appointing electors within their jurisdictions. Currently, presidential electors are appointed by holding popular elections in each of the states and in D.C., and the Constitution does not permit

(a) any repetition of voting to detect the will of the states or D.C. in electing state or D.C. electors to the Electoral College, and

(b) any repetition of voting to detect the will of elected (or appointed) electors (i.e. the Electoral College members from the states and from the District of Columbia).

2. The act of electing or appointing a President does not depend on the number of voters who may decide to vote for electors in the states of their residence and in D.C. Even if all the state eligible voters from any state (or eligible voters from D.C.) decide (a) not to vote for presidential electors at all, or (b) to vote against all the slates of the state (and D.C.) electors, the electors who are to represent the states (and D.C.) in the Electoral College will be appointed by the state and D.C. That is, Article 2 of the Constitution obliges every state to appoint state electors to the Electoral College in line with the manner of appointing state electors determined by the state legislature. Analogously, Amendment 23 of the Constitution obliges the District of Columbia to appoint its presidential electors to the Electoral College in line with the manner of appointing presidential electors determined by Congress for D.C. (In 1973, however, Congress officially transferred this authority to the administration of the District of Columbia.) The Constitution obliges all the electors to vote in their respective states and in the District of Columbia on the same day, which is currently the first Monday after the second Wednesday of December of the election year.

3. Making changes to the presidential election system that go beyond the authority of the states can be done only in the form of amendments to the Constitution. A proposal to consider a constitutional amendment is to be approved by either a two-third majority of votes cast in each of the two Chambers of Congress or by a special Convention that Congress may call for at the request of state legislatures from a two-third majority of all the states. To become part of the Constitution, every thus-approved amendment is to be ratified by either the state legislature in each of any three-fourths of all the states or by state Conventions called for in each of any three-fourths of all the states.

4. Any intermediate results of the work of the presidential election system can be challenged only in court (as happened, for instance, in the course of the 2000 election, when the voting results in the state of Florida regarding the composition of the state electors to represent the state in the Electoral College were challenged).

5. Each state and the District of Columbia can change the manner of appointing their presidential electors independently of the other states.

From the author's viewpoint, the listed merits of the system are fundamental, make this system unique, and may explain why this system has been in use from more than 220 years. 


\subsection{Embedded Deficiencies of the System}

The following description of substantial deficiencies of the presidential election system takes into consideration only (a) provisions of the Constitution relating to the presidential election system, and (b) the Supreme Court rulings that explicitly determine how one should understand these provisions. It is these provisions and rulings rather than any

- opinions of the Supreme Court judges that are expressed in the course of discussing any constitutional matters,

- interpretations of both constitutional provisions and the above-mentioned opinions by constitutional scholars, and

- numerical estimates of the chances of weird, undesirable, and extreme situations to emerge in the course of presidential elections

that constitute the basis for this description. Certainly, the system has other deficiencies; however, those under consideration in this paragraph are the deficiencies embedded in the Constitution that may eventually cause the intervention of the Supreme Court in the election process.

1. Constitutionally, presidential electors are free agents, i.e., they are free to make their decisions in voting for both a President and a Vice President. The Constitution does not limit any elector (i.e., any member of the Electoral College) in her/his decision to vote in the Electoral College. That is, each elector can (a) vote for any two persons (for one as President and for the other as Vice President), (b) cast one of the ballots or even both ballots blank, or (c) cast the ballots that cannot be recognized as votes favoring any person. This state of affairs takes place despite the fact that

- every elector from a state or from the District of Columbia belongs to a slate of electors submitted by the pair of presidential and vice-presidential candidates heading this slate in the state and in the District of Columbia, as well as in each congressional district of the states of Maine and Nebraska, and

- it is assumed that every member of the Electoral College (elector) from every state and from the District of Columbia will vote in favor of the pair of the candidates whose slate of electors (a) won in this state, in the District of Columbia, and in congressional districts of the states of Maine and Nebraska, respectively, and (b) contains the name of this elector.

Moreover, the above-mentioned two persons do not need to be either presidential or vice-presidential candidates in the election year.

Currently, election laws in 21 of 50 states do not oblige a state elector to favor presidential and vice-presidential candidates who head the slate of electors that (a) is to represent the state in the Electoral College, and (b) contains the name of this elector. (These 21 states currently control 208 out of 538 electoral votes in the Electoral College.) Five of the other 29 states have election laws punishing 
faithless electors. However, the constitutionality of these laws has never been challenged, and these laws have never been put to a test. Even under these laws, the elector may be punished only after she/he has cast the vote in the Electoral College. So, generally, these laws may not affect the elector's decision. In 2008, two states from the 29 states passed election laws that allow these states to nullify votes of faithless electors. However, the constitutionality of these laws has never been put to a test either.

The Supreme Court has never ruled that an elector must vote in line with the will of the state which this elector represents in the Electoral College. Yet different opinions on this matter have been expressed by the Supreme Court members in the course of considering various constitutional issues.

Examples of faithlessly cast votes by electors in the Electoral College are well known (see, for instance, Chap. 2 and the books [4, 6, 8]).

Thus, constitutionally, results of voting of more than 200 million eligible voters in the country and those of voting in the Electoral College in an election year may not necessarily coincide.

As mentioned earlier (see Sect. 2.2), theoretically, if for whatever reasons, all the appointed presidential electors vote faithlessly (by casting ballots that cannot be recognized as votes favoring presidential and vice-presidential candidates), the only provision to complete the election would then be the Twelfth Amendment, provided the Supreme Court confirmed that "the Vice President," mentioned in the amendment, is the sitting one and attributed (only) definition (b) (see Chap. 3) to the verb "to qualify" from the Twentieth Amendment.

2. The text of the Twelfth Amendment leaves it unclear how many persons (two or three) should be voted for as President in an election of a President thrown into the House or Representatives, when (a) at least three persons have received electoral votes as President in the Electoral College, and (b) none of these persons has received a majority of votes of all the appointed electors as President in the Electoral College.

Indeed, according to the Twelfth Amendment, no more than three persons rather than two or three persons exactly can be voted for as President in the House of Representatives in an election of a President thrown into Congress.

3. The text of the Twelfth Amendment leaves it unclear how two persons who are to be voted for as Vice President in an election of a Vice President thrown into the Senate, should be selected when (a) none of the electoral vote recipients has received a majority of the votes of all the appointed electors in the Electoral College as Vice President, and (b) at least three persons voted for as Vice President in the Electoral College have received one and the same greatest number of votes.

From the author's viewpoint, these embedded deficiencies make the U.S. presidential election system vulnerable and dependent on decisions of particular individuals rather than dependent only on constitutional provisions and legislations of Congress authorized by these provisions. 


\subsection{Some Urgent Problems of the System}

A brief description of some urgent problems of the existing presidential election system is based on the analysis of opinions on this system expressed by some political leaders, American voters, journalists, commentators, etc. These opinions do not reflect to what extent this system is in line with its underlying ideas and principles reflected in the Constitution and with the Supreme Court decisions on matters relating to presidential elections.

1. The U.S. presidential election system is quite complicated to understand all its details in depth. Despite this system being studied in American schools, a sizable number of American voters are convinced that on Election Day-i.e., on the first Tuesday next after the first Monday in the month of November of the election year - they vote for President and for Vice President. Since only the names of pairs of presidential and vice-presidential candidates heading the slates of state and D. C. electors appear on the (short) ballots, many voters do not know that they do not vote for these pairs of presidential and vice-presidential candidates. American voters vote in their respective states and in the District of Columbia only for the slates of electors submitted by the pairs of presidential and vice-presidential candidates who compete in the states (and in D.C.), as well as in each congressional district of the states of Maine and Nebraska. Moreover, constitutionally, even this limited participation of voters in every state in electing presidential electors fully depends on the will of the state legislature. The Constitution allows the state legislature of every state to appoint all state electors in the Electoral College by themselves, without holding any election for these electors in the state. Many Americans do not understand that the presidential election system can cause election outcomes undesirable to them, and the election result of the 2000 presidential election in Florida seems to illustrate this.

2. As mentioned earlier, since 1824 , there exists a tradition of counting "votes of all the voting voters" received by (the electors of) presidential candidates in all the states (and since the 1964 election, in the District of Columbia as well). The tally of all these votes, which does not have any legitimacy, is called the "national popular vote." This tally has this name despite the fact that, formally, it is a sum of the votes cast by eligible voters in different states and in D. C. for different slates of electors. Four times - in 1824, 1876, 1888, and 2000-the Electoral College elected President those presidential candidates who did not win the tallied national popular vote. Each time, this discrepancy was negatively received by the American people.

Available poll results bear evidence that an overwhelming majority of the respondents believe that a President should be elected in direct popular elections by American voters rather than by the Electoral College. However, all the attempts to initiate a constitutional amendment to change the existing presidential election system have so far failed. 
3. In the framework of the existing election system, votes of the voting voters have the same weight in determining the voting results only within a state and within the District of Columbia. This causes discontent among a sizable number of American voters, who believe that Presidents should be elected according to the principle "one person, one vote." It is this principle that is in use in all the American elections, except for presidential ones.

4. The deployment of the "winner-take-all" principle by state legislatures in 48 states and in the District of Columbia in electing presidential electors causes election campaigns of the major party candidates to focus on a few (10-15) so-called "battleground" or "swing" states. In each of these "swing" states, the number of votes supporting pairs of presidential and vice-presidential candidates from two major political parties turns out to have been close (or even almost the same) for the last 20-30 years. In each of the other so-called "safe" statesmany of which are densely populous ones, such as California, Texas, New York, and Florida - an overwhelming majority of all the voting voters usually prefer the candidates from one of the two major political parties in all the elections (except for, maybe, elections of the governors). In the framework of the "winner-take-all" principle, presidential candidates do not have any reason to actively campaign in the densely populous states. Such a tendency causes a great deal of discontent in many American voters from these "safe" populous states. Many of them strongly believe that presidential elections should be held according to the principle "one person, one vote" in the framework of direct popular elections.

The author believes these problems to be urgent, since their presence in the system affects the confidence of American voters on the fairness of the U.S. presidential election system.

\subsection{Seven Major Topics Relating to Presidential Elections}

In recent years American society has become deeply divided about whether the current election system is fair and serves the country well. Those who believe that it is and does, do not even say that the U.S. cannot talk about how democratic national elections are in other countries as long as its own presidential election system does not serve the popular will.

Many Americans support the idea to do away with the Electoral College and elect presidents by popular vote, whereas others strongly oppose such a move and assert that it would weaken the federal structure of government. The accuracy of counting the votes cast remains in question for a sizable part of the electorate. Some voters believe that partisan authorities may artificially design voter queues to deter voters from voting in places in which support of their political opponents is substantial. There is no consensus on whether presenting a voter ID at a polling station should be a must, and whether convicted felons should retain the right to vote. 
Finally, American society is becoming more and more concerned regarding the influence that numerous pre-election polls, sponsored by the media, may have on the voter turnout and election outcomes.

Strengthening the confidence of the American people in institutions of the U.S. democracy and encouraging eligible voters to exercise their right to vote are a challenge. As mentioned earlier in this book (see Chap. 7), the existing presidential election system is not easy to understand in depth, which leaves many eligible voters unaware of the value of their vote in presidential elections. An unsatisfactory civics education of both today's and future voters makes them vulnerable to both partisan political manipulation and ideological propaganda.

The American people, have both the right and the obligation to know how the existing presidential election system serves the nation so that they can decide (a) whether the whole system or any part of it should be replaced with other election mechanisms, and (b) what can be done within the existing system to address the above issues.

Public debates on the following seven major topics relating to the election system are long overdue: (a) The Electoral College v. the National Popular Vote plan and other plans to improve the current election system; (b) voter identification: how to suppress voter fraud while not suppressing voter turnout; (c) Election Day procedures and the integrity of the election process; (d) polling and elections: whether society is informed or "brainwashed" by the media regarding how election campaigns really develop; (e) voting technologies: how far the technologies have advanced since the 2000 Florida election in making the American people sure that every vote cast is counted; (f) civics education: what Americans know, and what they do not know about the election system that makes more than $40 \%$ of all eligible voters not interested in participating even in presidential elections, and (g) who should govern the national televised presidential debates, and how these debates should be governed.

Though some of these topics have been addressed in surveys regarding the election system, for instance, in [78-80], as well as in numerous publications on the related issues, for instance, in [81], American society remains polarized regarding these issues, and further studies of the issues within the topics are needed. The following studies in each of the issues seem urgent:

The Electoral College. Since the 2000 election, a sizable part of society has shared the belief that a person who has received the most votes should be President. In contrast, many voters and residents continue to believe that despite all the controversies whirling around the current system, this system best reflects the preferences of the states, which is the underlying idea of the Electoral College. The emergence of the National Popular Vote (NPV) movement, aimed at changing the current election system without amending the Constitution, its strong support by a part of society, and an equally strong rejection of the NPV idea by another part of society bear evidence that both above-mentioned beliefs have grounds and cannot be ignored any longer.

The originators and proponents of the National Popular Vote plan for changing the current election system interpret the provision of Article 2 of the Constitution 
favorable to their cause. That is, they assert that a compact formed by the states controlling at least 270 electoral votes combined can collectively decide who should be the next President, no matter what the rest of the country decides [5]. Certainly, this interpretation of the above constitutional provision is no more than a particular belief of a group of people, and it cannot be declared true or false until supported or rejected by the Supreme Court, as in the case with any constitutional matter.

However, this interpretation has already become a public policy currently in ten states-Maryland, New Jersey, New York, Illinois, Rhode Island, Massachusetts, California, Vermont, Hawaii, Washington - and in the District of Columbia, (currently) accounting for 165 electoral votes.

Opponents of the plan assert that not only does this plan violate the Constitution, in particular, the Equal Protection Clause from the Fourteenth Amendment, but that the NPV plan promises to the voters something that it cannot deliver-the equal interest of all the presidential candidates in campaigning in all the states [1].

The originators and proponents of the NPV plan blame the "winner-take-all" method for awarding state electoral votes for dividing the country into "safe" and "battleground" states and localizing the election campaign only in the "battlegrounds." Yet this plan is based on methods like "winner-take-all" in which a voter in a state cannot vote for electors from different slates of state electors.

The opponents of the NPV plan suggest that under the plan, the country will be divided into "battleground" densely populated metropolitan areas, where most voting voters reside, and rural, sparsely populated areas. They suggest that voting voters in rural areas constitute a small percentage of all voting voters and can be ignored by the candidates in any presidential elections, except for extremely close ones, rare for large electorates. Moreover, they suggest approaches to changing the system to treat the small- and medium-size states more fairly, which is likely to encourage presidential candidates to campaign in small states [1, 18, 22].

Should any group of states opposing the NPV plan decide to use methods for awarding state electoral votes other than the "winner-take-all," the "tally" of votes cast for electors of presidential candidates will no longer represent the popular will. The electoral votes that the compact of states would award according to the above "tally" under the NPV rules could no longer be viewed as those awarded on behalf of the whole country $[1,33,58]$.

Without consensus in society on the NPV plan, and without a decision on its constitutionality by the Supreme Court, it may happen that only the state-signatories to the NPV compact will be contributors to the "tally" of votes cast for slates of presidential electors. If this were the case, the country would become divided into the states that would insist on following the current election rules, which could favor candidate A, and the state-signatories to the NPV compact, which would declare candidate $\mathrm{B}$ the election winner $[33,58]$.

The issue of changing the current election system in any manner should become a subject of public discussion, and possibly, a referendum, where the American people can vote on any plan offered as a replacement for the current system. 
Voter Identification. Voter ID laws that some states have already instituted and some states would like to institute are a public policy concerning the integrity of the election process. Currently, there is no consensus in society on whether any such laws should be passed. Some prominent lawmakers, public figures, journalists, and voters believe that election fraud cannot be avoided unless every voter is required to present an ID at the polling station. Some others believe that this requirement is unnecessary due to an insufficient amount of fraud caused by the absence of voter IDs, whereas its enforcement will suppress voter turnout, especially that of minorities and elderly voters [82, 83].

Voter ID laws are not federal but state public policies, and these policies vary across the states. According to the National Conference of State Legislatures [83], currently, seventeen states (Georgia, Indiana, Kansas, Mississippi, North Dakota, Tennessee, Virginia, Texas, Wisconsin, Alabama, Florida, Hawaii, Idaho, Louisiana, Michigan, Rhode Island, and South Dakota) require a photo ID, whereas another 16 states (Arizona, Ohio, Alaska, Arkansas, Colorado, Connecticut, Delaware, Kentucky, Missouri, Montana, New Hampshire, North Carolina, Oklahoma, South Carolina, Utah, and Washington) require some form of a non-photo ID or its alternatives at the polling stations. Among the above seventeen states, nine states (Georgia, Indiana, Kansas, Mississippi, North Dakota, Tennessee, Virginia, Texas, and Wisconsin) allow the voters who fail to provide a voter ID to vote on a provisional ballot (though such an ID is required by the state law). However, these voters must provide an acceptable form of ID later on (within a few days after the election) to have their provisional ballots counted. In the other eight states (Alabama, Florida, Hawaii, Idaho, Louisiana, Michigan, Rhode Island, and South Dakota), the voter without an ID is allowed to cast a provisional ballot if either this voter signs a certain paper (for instance, the affidavit of identity) or a poll worker vouches for the voter. In any case, the eligibility of the voter is verified though no action from the voter is required.

At the same time, cases challenging both the status quo and the attempts to block voter ID laws are pending in several states.

There are conservative groups in the country that claim to have witnessed the registration of sizable numbers of ineligible and even non-existent voters, whereas there are liberal groups who claim that the voter fraud has never been sufficient enough to pass voter ID laws in the first place. Thus, the right of eligible citizens to vote in any election should not be compromised by any state laws, and the right of all eligible voters to have only legitimately cast votes counted should not be compromised either.

Election Day Procedures. Voting queues are another issue relating to the integrity of the election process, especially in federal elections, which constitutionally are conducted under different state laws.

Voter queues in presidential elections drew national attention when the 2000 and 2004 nail-biter elections warned American society that the queues might have affected the outcomes of both elections. Published studies suggest that, in the recent elections, long lines have contributed to discouraging from voting up to $2 \%$ of all eligible voters, which could have made a difference in close elections in particular 
"battleground" states. However, the voter queue problem, most recently actively discussed in the country during the 2008 election, does not seem to have stirred much interest.

In the 2000 election, George W. Bush won the presidency by a margin of just 537 votes in Florida. Thus, if at least 538 Floridians who came to the precincts did not have a chance to vote due to the widely reported long lines, one cannot be certain regarding the fairness of the election outcome [84].

In the 2004 election, fewer than 119,000 Ohio votes might have decided the election outcome. Bipartisan accounts suggest that in Columbus, an average of 21 would-be voters per precinct were discouraged by reported waits of up to fourteen hours. Simple arithmetic suggests that if this rate of discouragement held in all 12 of the most populated Ohio counties, with 6560 precincts-where official tallies showed John Kerry won a majority of votes - the election result might have been different [84, 85].

Election queues mostly form when the number of voting machines and support personnel are insufficient to handle swiftly the voters entering the polling station. Culprits include statistical underestimation, incompetence, equipment malfunction, and voter inexperience, especially in dealing with new machines. However, a deliberate manipulation may also be a factor [85].

Certain voting precincts can be intentionally "understaffed" with voting machines and personnel. Creating queues can be a potent weapon of partisan election authorities for suppressing voters believed to favor the other party. Among possible abuses that compromise elections, this tactic is difficult to detect, much less to prove. As there are no "exit polls" of voters who gave up because of long lines, red flags are not raised, and stealth disenfranchisement is a real possibility [86].

Malfunctions of voting equipment in the 2000 presidential election led to the Help America Vote Act (HAVA), passed by Congress in 2002 [87]. In contrast, the deployment of voting machines still does not have any federal oversight [85].

Service science suggests that establishing and enforcing voting standards, such as the maximum wait time to cast a vote, is the key to avoiding long lines on Election Day. Making a maximum waiting period a federal standard would provide "accessibility equity" for all voters [88].

The absence of reasonable voting standards is a double-edged sword. Partisan election administrators can artificially design voter queues in particular precincts to discourage would-be voters favoring their political opponents. Election administrators interested in fairly conducting elections do not have grounds to substantiate their requests for state or federal funds to meet even minimum expectations of voting voters (assuming that the administrators know how to meet them).

Polling and Elections. Predicting the outcomes of American presidential elections has become a business of the media with millions of customers both in the U.S. and around the world. While the predictions as such are undoubtedly entertaining, they affect the decisions of voters receptive to the opinions of political pundits, journalists, hosts of radio and TV talk shows, etc. Also, the prediction of the election outcome may affect the campaigns of presidential candidates due to changing the mood of potential financial donors to contribute to the "war chests" of 
particular candidates. The closer the election, the more attentive are the world financial markets to the predictions [89]. There are well-studied bandwagon and underdog effects of election outcome predictions $[6,80]$, which suggest that predictions of presidential election outcomes are a powerful weapon capable of affecting these outcomes.

The most important effect the predictions of presidential election outcomes have is that on voter turnout, discouraging from voting those voters who trust the predictions both favorable and unfavorable to their favorites, no matter whether these predictions are trustworthy or misleading. However, despite the obvious impact of the outcome predictions on the voter turnout, the problem has never been studied in depth.

Voting technologies. Voting technologies, especially voting machines, have been a focus of society since the 2000 election. Several studies, including those conducted in the framework of the CALTECH-MIT project, have been done, and research in the field continues.

From the CALTECH-MIT project, some conclusions have been drawn on what impact voting technologies have had on the so-called residual ballots, i.e., blank, overvoted, and undervoted ballots, and several security issues associated with the use of electronic voting machines have been identified and studied. A summary of some of these studies has been presented in several surveys, for instance, in [90, 91].

Obviously, the accuracy of counting the votes by voting machines remains among the major issues affecting the integrity of the election issues and the quality of the whole election system.

Civics Education: Civic studies of the presidential election system are mandatory in American schools. Yet future voters study this subject superficially, without understanding the principles underlying the current election system, which the Founding Fathers embedded in the Constitution. Nor do they understand the value of votes cast by voting voters in the election under any particular rules of determining the election winner, including the Electoral College ones [92, 93].

The basic rules for determining an election winner should be surveyed and discussed, and educational materials on the subject, including those currently available on the Internet [94], should become part of civics education. Also, discussing various voting rules will offer a comparative analysis of the pros and cons of these rules, as well as an analysis of the perspectives on their use in U.S. federal elections, including presidential elections.

National Televised Presidential Debates. According to the available data [95], in 2012, there were 30,700,138 members of the Republican Party and 43,140,758 members of the Democratic Party. Among the 129,237,642 voting voters in the 2012 presidential election, 1,108,805 voters favored minor-party candidates [31]. Thus, even if all the members of both major parties voted in the 2012 election, about 54 million voting voters were independents. This number greatly exceeds the number of members of either major party at that time. This simple arithmetic seems to be in line with the Gallup Poll results of January 11, 2016, which show that $42 \%$ of American adults consider themselves independents [96]. 
Yet one may argue that no matter how many voters call themselves independents, together, two major-party presidential candidates usually receive more than $95 \%$ of all the votes cast. In the 1992 and 1996 elections, however, they received less than 81 and $91 \%$, respectively [31], but these two elections were an exception. The participation of a strong independent candidate in the national televised presidential debates in the 1992 election substantially affected that election outcome. At the same time, his absence from the national televised debates in 1996 (though as a candidate from the Reform Party in that election), apparently, contributed to a substantial drop in his popularity on Election Day.

The Commission on Presidential Debates (CPD) - a private, non-profit organization formed in 1987- has had a monopoly on holding presidential debates since the 1988 election. Soon after the Commission was formed, the League of Women Voters decided to quit sponsoring these debates. This happened once it became known that the election campaigns of the two major party candidates had reached a secret agreement on how the debates should be held and ruled [97].

Neither the Constitution nor any federal statutes regulate these debates. The Federal Election Commission (FEC) regulations allow any 501(c)(3) and (c)(4) tax-exempt organization to hold federal candidate debates if it does not endorse or oppose political candidates or parties. The only requirement to be a "staging organization" for these debates is "to follow pre-established criteria on which candidates may participate in the debates" and not to use the "nomination by a particular political party as the sole objective criterion to determine whether to include a candidate in a debate" [98].

The CPD rules require persons interested in participating in the national televised presidential debates (a) to achieve at least $15 \%$ of the popular support on national polls conducted by "five selected national public opinion polling organizations," and (b) to be constitutionally eligible to the office of President and to be on the ballot in states controlling at least 270 electoral votes combined [99, 100].

Nobody knows which particular polls should be trusted and (why), when the support is to be demonstrated (and for how long), and whether all the presidential nominees are in the question of the top line. As egregious as this may seem, in the most developed democracy in the world, the CPD, a private firm, is free to dictate its fuzzy rules for presidential debates - a matter of national importance.

The historical "jump" of Ross Perot from $8 \%$ of the popular support before the televised debates to almost $19 \%$ on Election Day 1992 suggests that with respect to non-major party candidates, the CPD rules are a "Catch 22" [99]. Without gaining publicity via televised debates with major party candidates, a non-major party candidate is unlikely to achieve $15 \%$ of the public support. Yet without this support, the CPD does not let the candidate into these debates.

While the CPD claims to be non-partisan towards either major party, its rules look completely partisan towards all the other political parties and independent candidates combined. Due to the CPD rules, in presidential elections, the American people are, in fact, forced to choose only between two major-party nominees, even 
if unfavorable ratings of either nominee exceed $50 \%$, which seems to be the case in the 2016 presidential election [101].

Thus, these rules leave more than $40 \%$ of independent voters underrepresented in presidential debates, as well as in presidential elections.

In the CPD televised presidential debates, both major-party candidates only name problems that concern Americans and promise to take care of them if elected. They can afford to do this since the non-major party candidates, willing to discuss these problems, are cut off from the debates even in the primary season. Nobody knows whether the promises made are trustworthy and even implementable (particularly, financially) since no solutions and calculations are offered. The debaters focus on personal attacks on their opponents and go after them on private matters.

The CPD debates look like cage fights. Agile and wily debaters win by personally harming their opponents, or making fun of them, or both. Particular issues, that lovely word of the candidates who often have no clue on how to deal with them in reality, are not discussed as deeply as they deserve. Nor are they often even mentioned. Instead of a competition of ideas, the debates offer only a comparison of candidate disadvantages.

Is this good for America?

The country can only lose by electing a President out of two candidates whose plans for the country have not been discussed in depth in front of interested voters and experts. The CDP discriminatory debate rules contribute to distorting the real preferences of the American people. If non-major party candidates participated in TV presidential debates, many independent voters would probably still favor major-party candidates. However, their choice would then be free rather than being affected by the CDP rules.

Can the non-major parties and independent voters change this status quo? Yes, they can.

The CPD would certainly change the debate rules if a strong competing force came into play, as usually happens in any private business.

Alternative TV debates and/or online debates are likely to draw the attention of both the American voters and all the presidential candidates, including the two major-party ones, especially if experts offer their opinions as well.

Three challenges associated with organizing and holding such alternative debates should be addressed.

First, the cost of technically communicating the debates to, for instance, the Internet audience, which will be much lower than that of the TV ones, needs to be covered. One should estimate the numbers and explore the sources of the coverage. Any alternative and/or online presidential debate staging organizations are to be allowed by the FEC to accept funds from labor unions and corporations to "defray costs incurred in staging candidate debates" [98]. Certainly, foundations caring about the election fairness should be allowed to sponsor such debates.

Though businesses will undoubtedly be glad to use this unique opportunity to advertize their products to millions of debate viewers, their contributions should be approved by the FEC in some form. The same is true for possible small private 
contributions from the interested audience, and the grass-root financing of Senator Bernie Sanders' 2016 campaign bears evidence that there is room for this.

Second, the alternative TV and/or online debates should be run completely differently from the CPD "shows" that are currently offered in the TV debates. Though there still may be certain reasonable thresholds to overcome to be eligible to participate in the debates [102], both established political parties and independent presidential candidates should be able to participate. Criteria to consider candidates established should be set by experts and approved by the American people rather than being arbitrarily set by the CPD.

To be considered established, a non-major party presidential candidate or an independent one should demonstrate a certain level of public support, both locally and nationwide, to appear on TV programs, radio talk shows, etc., i.e., become noticeable in the public arena. It is possible that several such established candidates would first need to debate among themselves on the Internet, on TV and radio programs, and in the state and national newspapers. All interested persons can start these activities well in advance of the presidential election season, and the activity results will reflect public interest in their ideas and programs. This interest, measured by the level of the public support attained, will either let or not let them overcome the thresholds to be allowed to compete with the major-party candidates in any national televised presidential debates. The experience of running such debates for non-major party candidates and for the "newcomers" has long existed in Europe, and this experience may be helpful.

Once the set of presidential candidates from non-major parties and independent ones to be on the alternative TV and/or online debates has been determined, a list of issues to be discussed at the debates should be suggested by the potential viewers. Each debate should cover a particular issue or a group of connected issues from the list. The candidates should understand that they would be better off to be aware of the specifics of the issues which are the subject of each debate, since they are to argue with each other and also with invited recognized experts in the field. These experts will explain to the audience in a simple manner whether each candidate's proposal is implementable, will not harm the American economy and/or security, and will not make problems even more complicated. As a result of these debates, all interested Americans will see who of the candidates (a) shares their values, (b) is the most capable of solving problems that concern today's America, (c) is more knowledgeable, and (d) the best prepared to run the country.

Third, the alternative TV and/or online debates should be organized in such a manner that the candidates from both major political parties would not refuse to participate in them. Currently, the Internet reaches tens of millions of American voters, and presidential candidates need to earn their support by Election Day. In the era of television dominance, presidential candidates could afford to ignore their non-major party opponents [103, 104]. Particularly, with online debates, no candidate will dare to refuse to debate and let the opponents take advantage of her/his refusal to reach millions of voters. Also, deep concerns of many Americans about the future of the country and their distrust for both the legislative and the executive branches of the government have reached a critical level, as the 2016 election 
campaign has demonstrated. At this state of affairs, one cannot any longer deprive concerned voters either from substantive debates on real problems that they face in their everyday lives or from seeing alternatives to both major parties. Any refusal to participate in substantive debates with non-major party candidates and experts may cost the major-party candidates a defeat in the election.

Alternative TV and/or online substantive presidential debates will not exclude the CPD debates but will help Americans see who best can solve the country's problems. The CPD debates should let the candidates demonstrate their ability to react quickly, look presidential, and lead. The alternative TV and/or online debates should let the voters judge which candidate understands their problems better and more deeply. However, making the debates of both types inseparable will keep any debate staging organizations from excluding established non-major party candidates and independents from the debates.

Certainly, the idea of running alternative TV and/or online presidential debates will likely engender a great deal of criticism, especially from the conservatives, since they may believe that such debates are a threat to the existing two-party political system. However, this could be the case only if both major parties veer far away from voter expectations. On the contrary, holding such debates may produce an outcome desirable to both major parties. That is, if the major-party candidates come to the debates better prepared and more convincing than all their opponents, they may gain party supporters and even new members for their parties.

In any case, presidential candidates from established non-major political parties and independents who have overcome the above-mentioned thresholds should not be deprived from participating in televised presidential debates by artificially imposed unreasonable discriminatory requirements that are impossible to meet. Nor should the voters be left by the major parties to choose a President exceptionally based upon the financial capabilities of these parties rather than on the merits of all the presidential nominees.

Alternative TV and/or online debates that allow the nominees of established non-major party candidates to participate will make every presidential election more accurately reflect the will of the people. All the people.

Finally, supporters of the two-party system may argue that alternative TV and/or online presidential debates will "siphon" votes from major party candidates and will likely throw the election into Congress. Even if this is the case, at least currently, the two-party House of Representatives will unlikely elect a President other than from a major party though it may produce a President who has lost both the popular vote and the electoral vote.

Also, it seems reasonable to remind the conservatives that throwing a particular presidential election into Congress and electing a President in the House of Representatives is part of the existing presidential election system. Moreover, as mentioned in Sect. 1.5, in designing this system, the Founding Fathers may not have expected the Electoral College to always elect a President. According to their vision, if the Electoral College failed, the final say would belong to the states as equal members of the Union. The Founding Fathers considered the Electoral College failure a result of the lack of consensus among the electors, particularly, 
due to the difference in their opinions on who is the best to fill the office of President. Under today's presidential election system, the same lack of consensus among American voters on who is the best to be President may lead to the same failure of the Electoral College to produce a President.

If the voters know how the existing U.S. presidential election system works, they will likely make the right choice, being aware of the consequences of their vote. The author hopes that both the outlined seven topics to be discussed in the course of election campaigns and the present guide to the U.S. presidential election system may help American voters make this right choice on Election Day.

Open Access This chapter is distributed under the terms of the Creative Commons Attribution 4.0 International License (http://creativecommons.org/licenses/by/4.0/), which permits use, duplication, adaptation, distribution and reproduction in any medium or format, as long as you give appropriate credit to the original author(s) and the source, provide a link to the Creative Commons license and indicate if changes were made.

The images or other third party material in this chapter are included in the work's Creative Commons license, unless indicated otherwise in the credit line; if such material is not included in the work's Creative Commons license and the respective action is not permitted by statutory regulation, users will need to obtain permission from the license holder to duplicate, adapt or reproduce the material. 